\title{
Mangroves and seagrass beds do not enhance growth of early juveniles of a coral reef fish
}

\author{
Monique G. G. Grol, Martijn Dorenbosch, Eva M. G. Kokkelmans, Ivan Nagelkerken*
}

Department of Animal Ecology and Ecophysiology, Institute for Wetland and Water Research, Faculty of Science, Radboud University, Heyendaalseweg 135, P.O. Box 9010, 6500 GL Nijmegen, The Netherlands

\begin{abstract}
Mangroves and seagrass beds have long been considered important nursery grounds for various species of juvenile reef fishes due to their higher abundances in these habitats compared to coral reefs. It is assumed that these putative nurseries provide juveniles with more shelter, higher food availability and higher growth and survival rates than on the reef. However, this nursery function is still ambiguous, and few experimental field studies have tested this hypothesis in these tropical habitats. In the present study, the growth rate of juvenile Haemulon flavolineatum and the availability of its preferred food were determined in seagrass, mangrove and coral reef habitats. It was hypothesized that somatic growth rates as well as the amount of preferred food are higher within these putative nurseries than on the reef (according to the nursery hypothesis). The growth of small juveniles (3.5 to $4.2 \mathrm{~cm}$ total length, TL) was studied at 2 Caribbean islands using in situ experimental growth cages. Gut content analysis of the caged fishes showed that Copepoda were by far the most consumed food items by juveniles in all 3 habitats. Copepoda in the plankton samples were more abundant on the reef than in the mangrove/seagrass habitats. Growth rates of fishes showed the same pattern: higher growth rates in length and weight (significant for Aruba, a trend for Curaçao), and a higher weight-length ratio on the reef compared to the mangrove/seagrass habitats. Based on these observations it appears that the coral reef would be a more suitable habitat for small juveniles, when not taking other factors such as predation risk into account. Nevertheless, the highest juvenile fish abundances are found in mangrove/seagrass nurseries where predation risk, but also growth rate, is lower. Therefore, it appears that a tradeoff exists between food abundance/ growth rate and predation pressure/mortality risk, where fish select habitats that minimise the ratio of mortality risk to growth rate.
\end{abstract}

KEY WORDS: Growth rates - Diet composition - Food availability - Mangrove/seagrass nurseries · Tradeoffs $\cdot$ Haemulon flavolineatum

\section{INTRODUCTION}

Shallow-water coastal ecosystems, such as mangroves and seagrass beds, are considered important habitats for various coral reef fish species and are thought to function as nurseries for their juveniles (Parrish 1989, Beck et al. 2001). Many field studies have shown that the highest juvenile densities of some coral reef fish species are found in back-reef shallow-water habitats, whereas the highest adult densities are observed on the coral reef (Nagelkerken et al. 2000a, Eggleston et al. 2004). It is assumed that the juvenile fish use habitats like mangrove and seagrass habitats for several months and migrate to the coral reef at the onset of maturity (Cocheret de la Morinière et al. 2002). Nagelkerken et al. (2002) identified 17 Caribbean coral reef fish species which presumably use mangroves and seagrass beds as nurseries ('nursery species', sensu Nagelkerken et al. 2000a). Comparative research in bays with and without mangroves and/or seagrass beds showed that juveniles of these nursery species were absent or found at very low densities in mangrove/ seagrass-poor bays (Nagelkerken et al. 2001). Studies in the Indo-Pacific (Dorenbosch et al. 2005) and in the 
Caribbean (Nagelkerken et al. 2002) on islands completely lacking mangrove and seagrass nurseries showed that adult fishes of several nursery species were completely absent or found at very low densities on the coral reef. Based on this it has been suggested that mangroves and seagrass beds contribute to the fish densities on the coral reef (Nagelkerken et al. 2000a, 2002, Dorenbosch et al. 2005).

Based on the above concept, Beck et al. (2001) developed a nursery-role hypothesis in which they stated that a habitat is a nursery if its contribution per unit area to the production of individuals that recruit to adult populations is greater, on average, than production from other juvenile habitats. In these nursery habitats, the greater contribution to adult recruitment must be supported by any combination of the factors: (1) density, (2) growth, (3) survival, or (4) movement from the nurseries to adult habitats (Beck et al. 2001). Dahlgren et al. (2006) suggested the same, but based on total productivity of a habitat type. So far, almost all studies in the last few decades have only investigated fish densities, often in just a single habitat, and mostly using different techniques (reviewed by Heck et al. 2003). Hence, the importance of these habitats as nurseries is still ambiguous (Beck et al. 2001, Heck et al. 2003). Only in the last decade, have studies focussed more often on density and size distributions of reef fish in multiple habitats (e.g. mangroves, seagrass beds, algal beds, sand flats and reef flats; Nagelkerken et al. 2000a,b, Christensen et al. 2003, Eggleston et al. 2004, Chittaro et al. 2005, Dorenbosch et al. 2005). However, comparative research among mangrove, seagrass and coral reef habitats on the other 3 nursery-role factors (growth, survival and movement) is practically nonexistent, as has been identified by all recent reviews (Beck et al. 2001, Heck et al. 2003). The few studies which have focussed on nursery-role factors other than density were mainly done in estuaries and salt marshes and not in coastal habitats such as mangroves, seagrass beds and coral reefs (e.g. Gillanders et al. 2003). Furthermore, the majority of the studies in estuaries and salt marshes focussed on invertebrate species (e.g. lobster, shrimp, crab and conch) and not on reef fish. Hence, quantitative data are largely lacking for coral reef fish to support the nursery hypothesis. In previous studies, we identified higher juvenile fish densities in mangrove and/or seagrass habitats than on the coral reef (Nagelkerken et al. 2000b, Dorenbosch et al. 2005). In the present study, we test the factor growth to further evaluate the nursery-role hypothesis.

Most coral reef fish begin their life as planktonic larvae that eventually settle onto the coral reef or in embayments/lagoons as early juveniles. During this first benthic life stage, mortality rates are very high, largely due to predation (Shulman \& Ogden 1987). At this moment, rapid growth is of crucial importance as it enables a newly settled fish to outgrow the most vulnerable size classes quickly, leaving a selective advantage over slow-growing fishes. At a certain stage, they will outgrow their initial shelter habitat. Therefore, fishes may need to shift between habitats during this life cycle to avoid predation or because of feeding or reproduction needs (Sutherland 1996). Selection of habitats by juvenile fish is based on the 'minimise M/G hypothesis', where fishes shift habitats in a way that maximises growth $(\mathrm{G})$ and minimises predation or mortality (M) risk (Dahlgren \& Eggleston 2000).

The high abundance of juvenile fish and the preference of larvae to settle in mangroves and seagrass beds is likely based on the minimise M/G hypothesis: these habitats may have lower predation risk because they provide excellent shelter against predators, a lower abundance of predators due to the distance away from the coral reef and a low predator efficiency due to relatively turbid waters in these habitats, while mangrove and seagrass beds possibly maximise growth due to a high food availability (Blaber 2000). The latter remains to be tested, however.

The aim of the present study was to test the hypothesis that juvenile coral reef fishes grow faster in mangrove and seagrass habitats than on the coral reef. This was done using experimental growth cages and studying in situ growth rates in length and weight of early juveniles of the common reef fish Haemulon flavolineatum for several months on 2 Caribbean islands (Curaçao and Aruba). Predation was excluded so that the factor growth could be evaluated independently. Gut contents of the fish and food abundance in the 3 habitat types were analysed to test whether the abundance of preferred food could be responsible for the observed juvenile growth rates.

\section{MATERIALS AND METHODS}

Study areas. The present study was carried out at 2 islands in the southern Caribbean Sea: in Spanish Water Bay in Curaçao, Netherlands Antilles, and along the southwestern coast of Aruba (Fig. 1). Spanish Water Bay is ca. $3 \mathrm{~km}^{2}$ in surface area and is situated on the southwestern side of Curaçao. The embayment is relatively shallow (depth $<6 \mathrm{~m}$ ) and harbours seagrass Thalassia testudinum beds and fringing mangroves Rhizophora mangle. The fringing coral reef in front of the embayment runs along the entire southwest coast of Curaçao. It starts from the shore with a narrow submarine terrace of 50-100 m width and turns into a drop-off at 7-12 $\mathrm{m}$ depth that slopes steeply to 50-60 m (Bak 1975). In contrast to Curaçao, Aruba has no embayments with mangroves and seagrass beds 


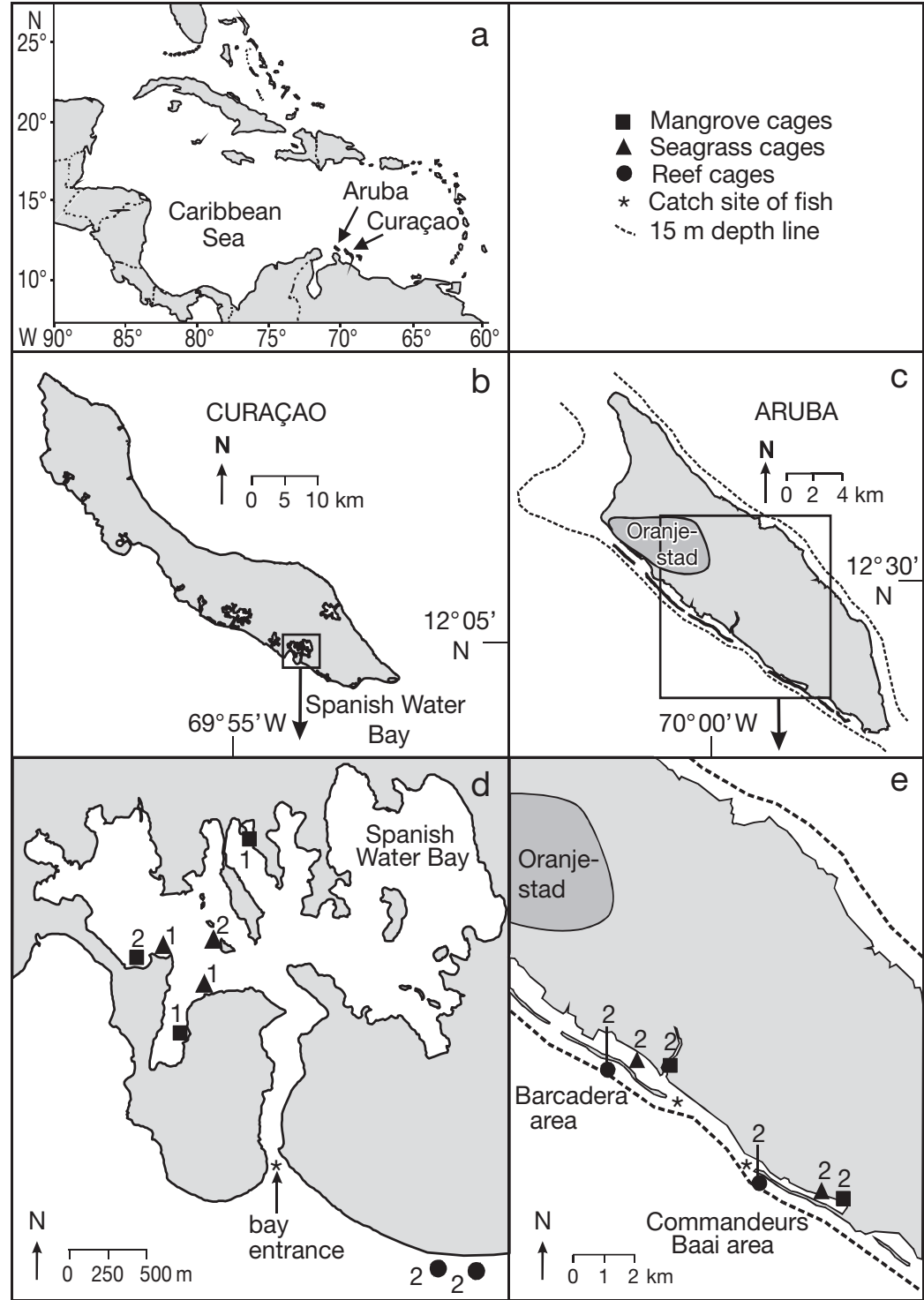

Fig. 1. (a) Research areas, locations of placement of the experimental growth cages and catch sites of juvenile Haemulon flavolineatum in (b) Curaçao and (c) Aruba. $(d, e)$ Number of cages per site like Spanish Water Bay, and no steep coral reef slopes are found either. Instead, Aruba has a large continental shelf with small coral cays along the southwestern coast. The chain of cays forms a large lagoon with seagrass $T$. testudinum beds and mangroves $R$. mangle, and protects the coast against strong wave action and ocean currents (Fig. 1). The fringing coral reef is located south of the cays and is characterized by a shallow terrace $(<8 \mathrm{~m}$ deep, $>100 \mathrm{~m}$ wide) and a drop-off at 8 to $12 \mathrm{~m}$ from where the reef gradually slopes to a depth of 25 to $30 \mathrm{~m}$, where a sandy plain starts.

The average daily tidal range on both islands is $0.3 \mathrm{~m}$ with a maximum of $0.55 \mathrm{~m}$ (de Haan \& Zaneveld 1959). Horizontal water clarity ranged on average between 4.0 and $7.8 \mathrm{~m}$ in the mangroves and seagrass beds, and between 17.2 and $29.5 \mathrm{~m}$ on the coral reef (Table 1), and was measured twice a month using a Secchi disk. Study sites in Spanish Water Bay and along the southwestern coast of Aruba have no freshwater input other than rain. Temperature and salinity were measured weekly using a handheld conductivity/ temperature/TDS meter (YSI 30 and CyberScan CON 410 for Curaçao and Aruba, respectively) and ranged in Curaçao from 30.1 to $30.5^{\circ} \mathrm{C}$ and from 33.2 to 33.5 , respectively, and on Aruba from 27.6 to $28.4^{\circ} \mathrm{C}$ and from 34.0 to 34.2 , respectively, among the 3 habitats (Table 1).

Studied species. This study focussed on the common reef fish species French

Table 1. Mean $( \pm \mathrm{SD})$ water salinities, temperatures and water clarities for the 3 habitat types (mangroves, seagrass beds and coral reef) where experimental growth cages for juvenile Haemulon flavolineatum were placed in Spanish Water Bay in Curaçao (2005) and along the southwestern coast of Aruba (2006), and the mean length, weight and weight-length (WL) ratio of the fish at the start of the experiment

\begin{tabular}{|lccccccc|}
\hline Island & Habitat & Salinity & $\begin{array}{c}\text { Temperature } \\
\left({ }^{\circ} \mathrm{C}\right)\end{array}$ & $\begin{array}{c}\text { Water clarity } \\
(\mathrm{m})\end{array}$ & $\begin{array}{c}\text { Length } \\
(\mathrm{cm})\end{array}$ & $\begin{array}{c}\text { Weight } \\
(\mathrm{g})\end{array}$ & $\begin{array}{c}\text { WL ratio } \\
\left.(\mathrm{g} \mathrm{cm})^{-1}\right)\end{array}$ \\
\hline Curaçao & Mangroves & $33.2 \pm 0.9$ & $30.5 \pm 0.8$ & $4.2 \pm 0.6$ & $4.2 \pm 0.2$ & $0.7 \pm 0.1$ & $0.2 \pm 0.0$ \\
& Seagrass beds & $33.5 \pm 1.0$ & $30.5 \pm 0.8$ & $4.6 \pm 1.8$ & $4.0 \pm 0.1$ & $0.7 \pm 0.2$ & $0.2 \pm 0.0$ \\
& Coral reef & $33.3 \pm 0.7$ & $30.1 \pm 0.7$ & $29.5 \pm 3.5$ & $4.0 \pm 0.2$ & $0.6 \pm 0.2$ & $0.2 \pm 0.0$ \\
& & & & & & \\
Aruba & Mangroves & $34.2 \pm 0.6$ & $28.4 \pm 1.1$ & $4.0 \pm 1.6$ & $3.8 \pm 0.0$ & $0.7 \pm 0.0$ & $0.2 \pm 0.0$ \\
& Seagrass beds & $34.1 \pm 0.8$ & $28.4 \pm 1.0$ & $7.8 \pm 3.6$ & $3.6 \pm 0.0$ & $0.5 \pm 0.0$ & $0.2 \pm 0.0$ \\
& Coral reef & $34.0 \pm 0.8$ & $27.6 \pm 0.8$ & $17.2 \pm 3.7$ & $3.7 \pm 0.0$ & $0.6 \pm 0.0$ & $0.2 \pm 0.0$ \\
\hline
\end{tabular}


grunt Haemulon flavolineatum. Juveniles of this species are highly abundant in Caribbean mangroves and seagrass beds and the adults are found on the coral reef (Nagelkerken et al. 2000a, Christensen et al. 2003, Eggleston et al. 2004, Chittaro et al. 2005). This species also recruits on the coral reef, although densities are much lower than in the mangroves and seagrass beds (Shulman \& Ogden 1987, Nagelkerken et al. 2000b). In the present study, relatively recently settled juveniles were used in the growth experiments. They feed on plankton during daytime, but shift to nocturnal feeding on zoobenthos when they grow larger (Ogden \& Ehrlich 1977, Cocheret de la Morinière et al. 2003). Studies on feeding behaviour confirmed this for juvenile $H$. flavolineatum in the mangroves and seagrass beds of Spanish Water Bay and showed that H. flavolineatum juveniles up to ca. $5 \mathrm{~cm}$ in length still feed in the water column during daytime (Verweij et al. 2006).

Growth study. Growth of juvenile Haemulon flavolineatum was studied in 3 habitat types (mangroves, seagrass beds and the coral reef) using in situ experimental growth cages. Predators were excluded from the cages to avoid interaction with the factor growth. Growth experiments were conducted in a total of 24 cages, with 12 at each island. In each habitat type, 8 cages (4 per island) were placed. The location of each cage depended on the availability of habitat type and its configuration (Fig. 1). At sites where 2 cages were placed (see Fig. 1), they were separated by at least $25 \mathrm{~m}$. Size of a cage was $1.5 \times 1.5 \times 0.7 \mathrm{~m}$. The frameworks were constructed using iron rods $(8$ and $10 \mathrm{~mm}$ in diameter for seagrass/mangrove and coral reef habitats, respectively) and covered with iron gauze with a mesh size of $6 \mathrm{~mm}$. The bottom was uncovered and exposed to the natural substratum. Closable windows $(30 \times 30 \mathrm{~cm})$ were constructed at 2 opposite sides to introduce and remove fish from the cages. At both islands, experimental cages were placed on the natural substratum in each habitat type at a depth between 1.2 and $5.8 \mathrm{~m}$. The iron gauze of the cages was scrubbed twice a week to remove algal growth and to preserve a good flow of water and plankton through the cages.

Juvenile Haemulon flavolineatum were caught on sandy/rubble areas located in-between the reef and the mangrove/seagrass beds (Fig. 1). Only fish with a minimum length of $3.5 \mathrm{~cm}$ and a maximum of $4.2 \mathrm{~cm}$ were used in the experiment. Total length (TL, to the nearest $\mathrm{mm}$ ) and total wet weight (to the nearest $\mathrm{mg}$ ) of each fish were measured in the field before introduction into the cages. In each cage, 20 small juveniles differing no more than $3 \mathrm{~mm}$ in length were introduced, and densities within the cages were thus 8.9 ind. $\mathrm{m}^{-2}$. No data on typical in situ densities of early juveniles were available to determine fish density in the cages. However, on Aruba as well as in Curaçao early juveniles are found in large schools of up to several hundreds of individuals (authors' pers. obs.). Similar schools of juvenile $H$. flavolineatum (up to $3 \mathrm{~cm}$ in length) were observed by Ogden \& Ehrlich (1977) on patch reefs surrounded by seagrass beds. Juvenile fish remained in the cages for on average $8 \mathrm{wk}$ in Curaçao (September to October 2005) and 6 wk on Aruba (July to August 2006). At the end of the experiment, fish were recovered from the cages, re-measured in length and weight and their gut removed and frozen directly.

Food availability. Since the studied juvenile Haemulon flavolineatum were still diurnal planktivores, densities of zooplankton were quantified in the water column at each site where cages were placed in the mangroves, seagrass beds and coral reef at both islands during the 2 study periods. The water layer just above the substratum was sampled twice inside and twice outside each of the 24 cages by hauling a plankton net (diameter mouth $25 \mathrm{~cm}$, mesh size 80 to $120 \mu \mathrm{m}) 6$ times along a $1 \mathrm{~m}$ long transect. Samples were taken inside as well as outside each cage to exclude the possibility that food availability in the cages was limiting for growth, and all samples were taken during daytime when these small juvenile grunts feed. All plankton samples were preserved in $70 \%$ alcohol and dyed with Bengal Rose before the total number and type of planktonic invertebrates were quantified using a stereomicroscope. All zooplankton was categorized to taxon level. To determine the diet of the fish, the content of the entire digestive tract of at least 13 juvenile fish per habitat type per island was quantified using the same taxonomic levels as for the food samples.

Data and statistical analysis. For each individual fish, the mean growth rate $\mathrm{d}^{-1}$ in length (GL) was calculated as:

$$
\mathrm{GL}=\left(L_{\mathrm{f}}-L_{\mathrm{i}}\right) t^{-1}
$$

where $L_{\mathrm{f}}$ is the length of each individual fish at the end of the experiment, $L_{\mathrm{i}}$ is mean length of fish per cage at the start of the experiment calculated by averaging the fork lengths of all introduced juvenile fish per cage, and $t$ is duration of the experiment in days for each individual fish. $L_{\mathrm{i}}$ was based on mean values since fish were not tagged individually and their individual initial weight or length could therefore not be identified at the end of the experiment. The growth rate $\mathrm{d}^{-1}$ in weight $(\mathrm{GW})$ was calculated similarly using weight data. In addition, the weight-length (WL) ratio of each fish removed from the cages was calculated. The WL relationship of captured fish is often used to assess growth (e.g. Keys 1928). Mean growth in length and weight and mean WL ratio per habitat were calculated by pooling all individual fish per habitat for each island 
and testing for statistical differences among habitats using 1-way ANOVAs. Homogeneity of variances was tested with a Levene's test. Multiple comparisons of means among the 3 different habitats were done using a Hochberg post hoc test. One cage on the reef of Curaçao and 2 cages on the reef of Aruba were not included in the analysis, because these cages were destroyed and all juveniles escaped.

The total number of individuals of all taxa found in the plankton samples was pooled per habitat and expressed per $\mathrm{m}^{3}$. Independent $t$-tests were used to test whether there was a significant difference in the number of Copepoda (the main food source of juvenile Haemulon flavolineatum) in the plankton samples between the inside and outside of the cages for the 3 habitats separately per island. Copepoda densities in the plankton were compared among the 3 habitats (separately for inside and outside the cages) using a 1 -way ANOVA after $\log (x+1)$ data transformation. Homogeneity of variances was tested with a Levene's test, and multiple comparisons in densities between habitats were analysed using a Tukey HSD post hoc test.

The number of food items of all taxa found in the entire digestive tract of a juvenile were quantified by eye and calculated as percentages of the total number found per taxa.

Data were analysed separately for each island, and all statistical analyses were performed using SPSS (version 14.5). Differences were significant if $p$-values were $\leq 0.050$.

\section{RESULTS}

On Aruba, a significantly higher mean GL and GW of Haemulon flavolineatum was found on the coral reef compared to the mangrove/seagrass habitats (Fig. 2a,b, Tables 2 \& 3). The mean GL and GW of fish

Table 2. Results of 1-way ANOVA on mean growth in length (GL), mean growth in weight (GW) and mean weight-length (WL) ratio of juvenile Haemulon flavolineatum comparing the 3 habitat types mangroves, seagrass beds and the coral reef for Curaçao and Aruba

\begin{tabular}{|lcccc|}
\hline Island & Variable & p-value & df & $F$ \\
\hline Curaçao & GL & 0.179 & 2 & 1.75 \\
& GW & 0.062 & 2 & 2.91 \\
& WL ratio & 0.018 & 2 & 4.20 \\
Aruba & GL & $<0.001$ & 2 & 11.21 \\
& GW & $<0.001$ & 2 & 32.95 \\
& WL ratio & $<0.001$ & 2 & 30.93 \\
\hline
\end{tabular}

in Curaçao were highest on the reef, although no significant difference was found among the 3 habitat types. At both islands, the mean WL ratio was significantly higher on the coral reef than on the seagrass beds (Fig. 2c, Tables $2 \& 3$ ). In addition, WL ratios were significantly higher on the reef than in the mangroves on Aruba. GL, GW and WL ratios did not differ signifi-
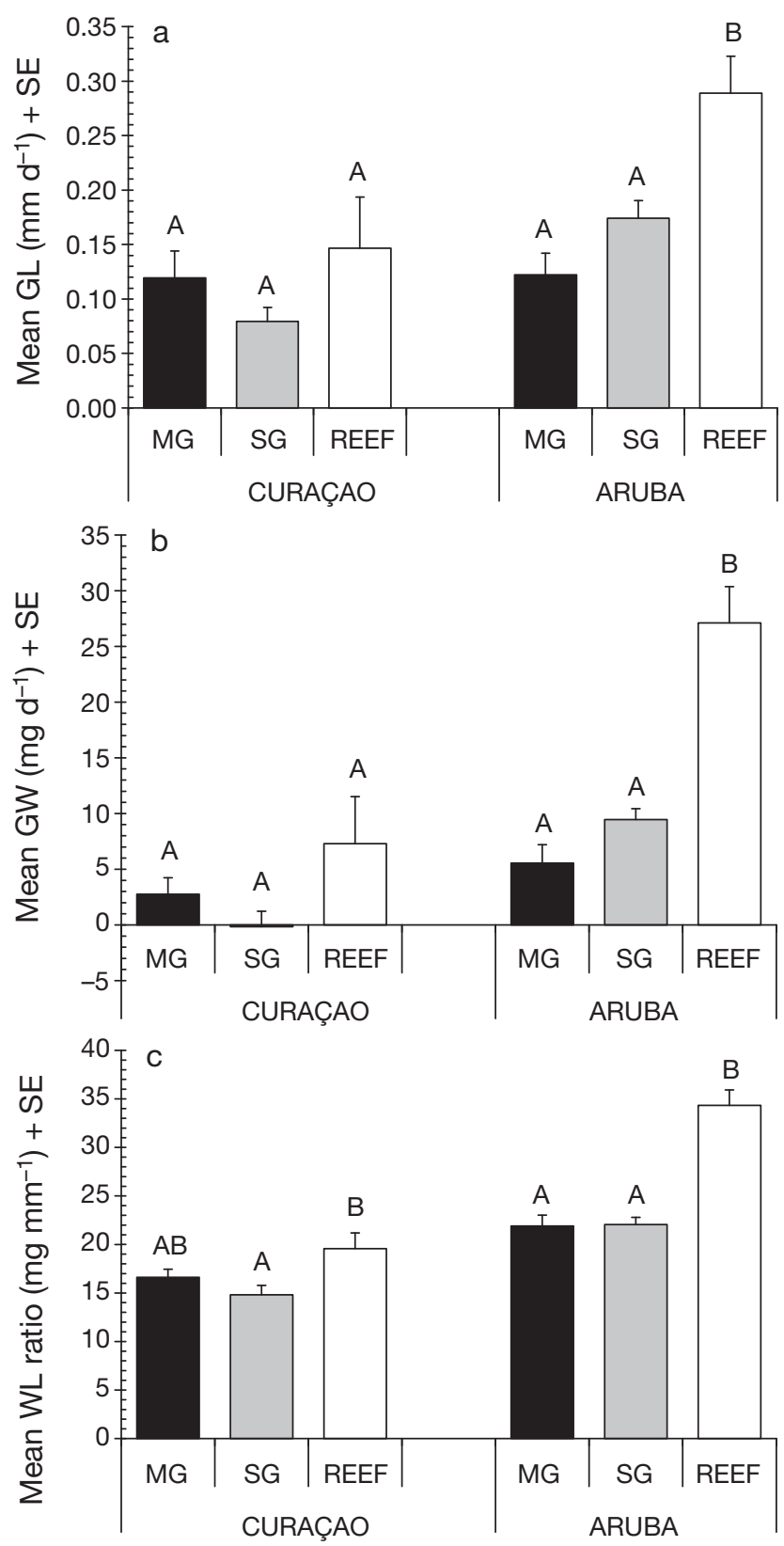

Fig. 2. (a) Mean growth in length (GL), (b) mean growth in weight (GW) and (c) weight-length (WL) ratio of juvenile Haemulon flavolineatum kept in experimental cages in mangroves (MG), seagrass beds (SG) and coral reefs (REEF) in Curaçao and Aruba. Different letters represent significant differences among the 3 habitat types per island 
Table 3. p-values of multiple post hoc comparisons (Hochberg's test) among the 3 habitat types mangroves, seagrass beds and coral reef, separately for growth in length (GL), growth in weight (GW) and weight-length (WL) ratio, for Curaçao and Aruba

\begin{tabular}{|cclcc|}
\hline Island & Variable & Habitat & Mangroves & $\begin{array}{c}\text { Seagrass } \\
\text { beds }\end{array}$ \\
\hline Curaçao & GL & Seagrass beds & 0.511 & \\
& & Coral reef & 0.864 & 0.222 \\
& GW & Seagrass beds & 0.557 & \\
& & Coral reef & 0.397 & 0.058 \\
& WL ratio & Seagrass beds & 0.471 & \\
& & Coral reef & 0.232 & 0.014 \\
Aruba & GL & Seagrass beds & 0.151 & \\
& \multirow{4}{*}{ GW } & Coral reef & $<0.001$ & 0.003 \\
& & Seagrass beds & 0.172 & \\
& Coral reef & $<0.001$ & $<0.001$ \\
& WL ratio & Seagrass beds & 0.999 & \\
& & Coral reef & $<0.001$ & $<0.001$ \\
\hline
\end{tabular}

cantly between mangroves and seagrass beds at either of the islands.

Juvenile Haemulon flavolineatum growth rates ranged from -0.2 to $0.7 \mathrm{~mm} \mathrm{~d}^{-1}$ and from -10.0 to $60.0 \mathrm{mg} \mathrm{d}^{-1}$, while the WL ratio at the end of the experiment ranged from 5.1 to $50.0 \mathrm{mg} \mathrm{mm}^{-1}$ (Fig. 3). On Aruba, the mode of the frequency distribution of all 3 variables on the reef was skewed to the larger growth classes compared to that of mangroves/seagrass beds, whereas in Curaçao the mode was more similar among habitats. In Curaçao, the 3 variables all showed a small peak for the larger growth classes.

In total, 80 juvenile Haemulon flavolineatum were introduced in the experimental growth cages per habitat type per island. In Curaçao, $43 \%$ of the fishes were recovered from the mangrove cages, $50 \%$ from the seagrass cages and $24 \%$ from the reef cages, while on Aruba 38, 54 and 19\% were recovered from the mangrove, seagrass and reef cages, respectively.

Gut content analysis showed that the diet of juvenile Haemulon flavolineatum mainly consisted of Copepoda (mean range 48 to $82 \%$, Table 4 ). Tanaidacea ( 0 to $25 \%$ ) and Ostracoda ( 2 to $21 \%$ ) formed a less important component of their diet. On the coral reef at both islands, juveniles consumed more Copepoda $(>75 \%)$ than in the mangroves and seagrass beds, while the contribution of Tanaidacea and Ostracoda to the diet was larger in the latter 2 habitats than on the coral reef.

Copepoda, the main food source of juvenile Haemulon flavolineatum, showed no significant difference in density between the plankton samples collected inside and outside the cages in any of the 3 habitat types of either island, except for the mangrove cages in Cura-
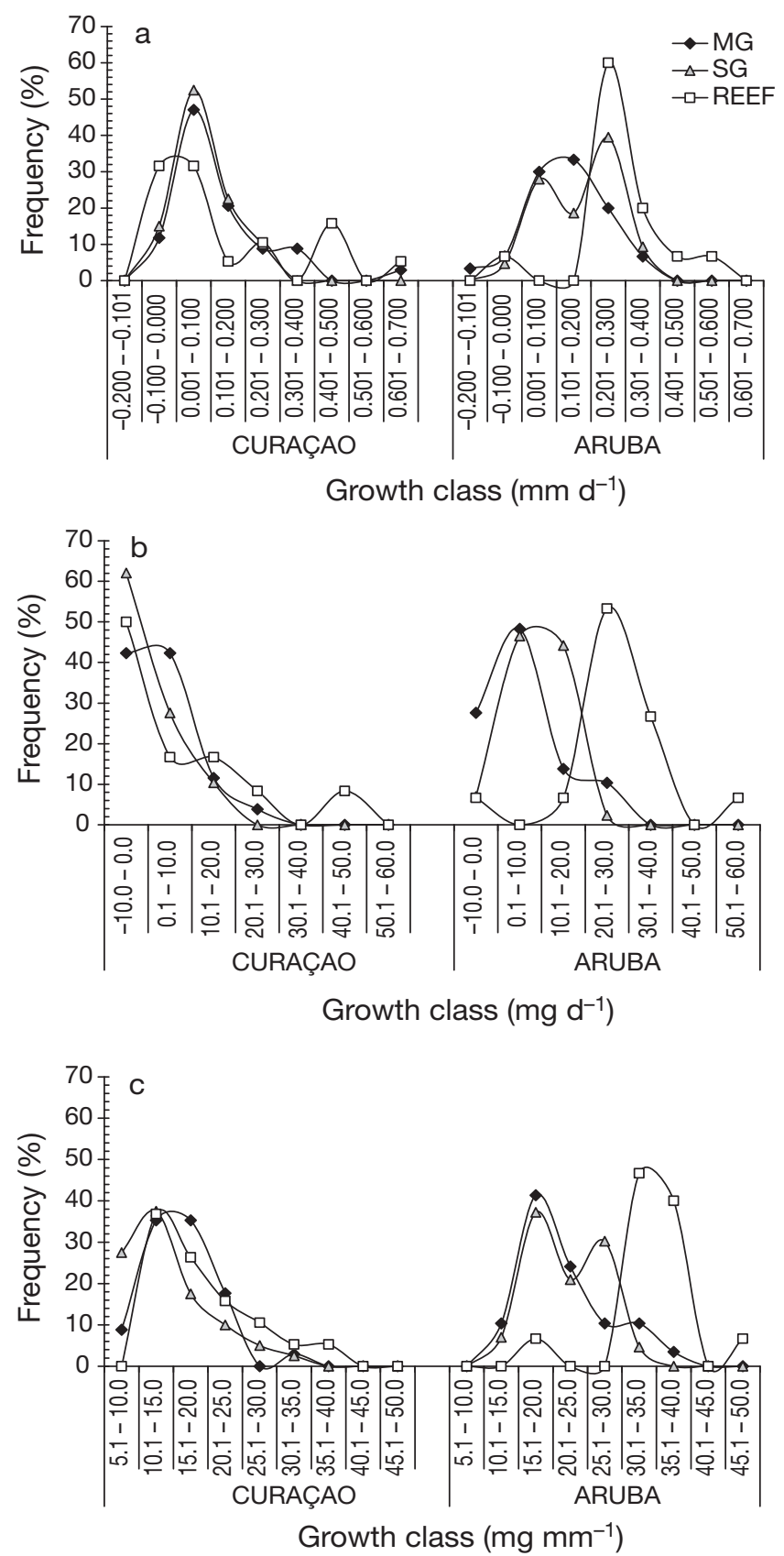

Fig. 3. Frequency distributions of (a) growth rate in length, (b) growth rate in weight and (c) weight-length ratio classes for Haemulon flavolineatum juveniles recovered from the experimental growth cages in mangroves (MG), seagrass beds (SG) and on the coral reef (REEF) at the end of the experiment in Curaçao and Aruba

çao where a significantly higher number of Copepoda was found outside the experimental growth cages (Table 5). In Curaçao, the total density of Copepoda was always significantly higher on the coral reef compared to mangroves and seagrass beds, inside as well as outside the cages (Fig. 4, Tables 5 \& 6). On Aruba, Copepoda densities did not differ significantly among 
Table 4. Gut contents of juvenile Haemulon flavolineatum recovered from experimental growth cages in mangroves, seagrass beds and coral reef in Curaçao and on Aruba. The mean $( \pm \mathrm{SD})$ length and weight of the recovered fishes $(\mathrm{N})$ and the mean percentage of Copepoda, Tanaidacea, Ostracoda and Rest group (all other less-common food species pooled) in the entire digestive tract

\begin{tabular}{|llccccccc|}
\hline Island & Habitat & $\mathrm{N}$ & $\begin{array}{c}\text { Length } \\
(\mathrm{cm})\end{array}$ & $\begin{array}{c}\text { Weight } \\
(\mathrm{g})\end{array}$ & $\begin{array}{c}\text { Copepoda } \\
(\%)\end{array}$ & $\begin{array}{c}\text { Tanaidacea } \\
(\%)\end{array}$ & $\begin{array}{c}\text { Ostracoda } \\
(\%)\end{array}$ & $\begin{array}{c}\text { Rest group } \\
(\%)\end{array}$ \\
\hline Curaçao & & Mangroves & 13 & $4.9 \pm 0.6$ & $0.9 \pm 0.3$ & $63 \pm 19$ & $16 \pm 14$ & $13 \pm 11$ \\
& Seagrass beds & 13 & $4.5 \pm 0.5$ & $0.8 \pm 0.5$ & $48 \pm 16$ & $25 \pm 27$ & $18 \pm 21$ & $10 \pm 9$ \\
& Coral reef & 13 & $4.3 \pm 0.2$ & $0.7 \pm 0.2$ & $76 \pm 19$ & $0 \pm 0$ & $2 \pm 5$ & $23 \pm 20$ \\
Aruba & Mangroves & 13 & $4.3 \pm 0.5$ & $1.0 \pm 0.4$ & $50 \pm 20$ & $17 \pm 14$ & $11 \pm 15$ & $21 \pm 21$ \\
& Seagrass beds & 13 & $4.5 \pm 0.4$ & $1.1 \pm 0.2$ & $53 \pm 30$ & $19 \pm 18$ & $21 \pm 23$ & $7 \pm 8$ \\
& Coral reef & 15 & $4.9 \pm 0.4$ & $1.7 \pm 0.4$ & $82 \pm 13$ & $4 \pm 5$ & $4 \pm 7$ & $10 \pm 8$ \\
\hline
\end{tabular}

Table 5. Results of independent $t$-tests on total Copepoda density in the plankton comparing the density inside and outside the experimental growth cages (within habitats), and results of 1-way ANOVAs on total Copepoda density in the plankton comparing the 3 habitat types mangroves, seagrass beds and coral reef for Curaçao and Aruba, inside (In) and outside (Out) the experimental growth cages

\begin{tabular}{|lllllcccc|}
\hline Island & Habitat & $\begin{array}{c}\mathrm{p} \text {-value } \\
\text { t-test }\end{array}$ & $\mathrm{df}$ & $F$ & $\begin{array}{c}\text { In/out } \\
\text { cage }\end{array}$ & $\begin{array}{c}\text { p-value } \\
\text { ANOVA }\end{array}$ & $\mathrm{df}$ & $F$ \\
\hline Curaçao & Mangroves & 0.012 & 14 & 5.50 & in & $<0.001$ & 2 & 16.54 \\
& Seagrass beds & 0.573 & 14 & 1.08 & Out & 0.002 & 2 & 8.08 \\
& Coral reef & 0.234 & 14 & 2.61 & & & & \\
Aruba & Mangroves & 0.510 & 14 & 0.05 & In & 0.096 & 2 & 2.64 \\
& Seagrass beds & 0.128 & 14 & 0.38 & Out & 0.055 & 2 & 3.35 \\
& Coral reef & 0.338 & 13 & 4.67 & & & & \\
\hline
\end{tabular}

Recently settled larvae and juvenile Haemulon flavolineatum are diurnal planktivores (Ogden \& Ehrlich 1977) up to ca. $5 \mathrm{~cm}$ in length (Verweij et al. 2006). At the end of the experiment, caged fishes in our experiment averaged between 4.3 and $4.9 \mathrm{~cm}$ in length among habitats on both islands, and they were still diurnal planktivores (authors' pers. obs.). Gut content analysis of the caged fishes showed that they primarily consumed Copepoda, with some additional feeding on Tanaidacea and Ostracoda in mangroves and seagrass beds. The diet composition of uncaged juvenile $H$. fla-

habitats inside the cages (although there was a trend of higher densities on the reef), and outside the cages the reef only harboured a significantly higher Copepoda density than the mangroves.

\section{DISCUSSION}

The results from the present study show that the mean growth of early juvenile Haemulon flavolineatum is not significantly higher within mangrove and seagrass nurseries as hypothesized earlier, but that on Aruba, instead, the fastest GL and GW, and highest $\mathrm{WL}$ ratios were found on the coral reef. A trend of a higher GW and GL on the reef was visible in Curaçao, while the WL ratio was significantly higher on the reef than on the seagrass beds. Individual growth of fish depends on several factors, such as food availability, food consumption, fish condition, predator pressure, competition and abiotic variables such as water temperature and salinity (e.g. Baltz et al. 1998, Connell 1998, McCormick 1998, Boeuf \& Payan 2001). The most likely factor explaining the differences in growth rates among habitat types in this experiment is food abundance; most other factors can be excluded here as discussed farther below. volineatum between 2.5 and $5.0 \mathrm{~cm}$ in length in Spanish Water Bay showed a similar result, in which mainly Copepoda (>83\%) and some Tanaidacea (12\%) were found in their digestive tracts (Cocheret de la Morinière et al. 2003). Also in an embayment in Bermuda fish of the genus Haemulon, including $H$. flavolinea-

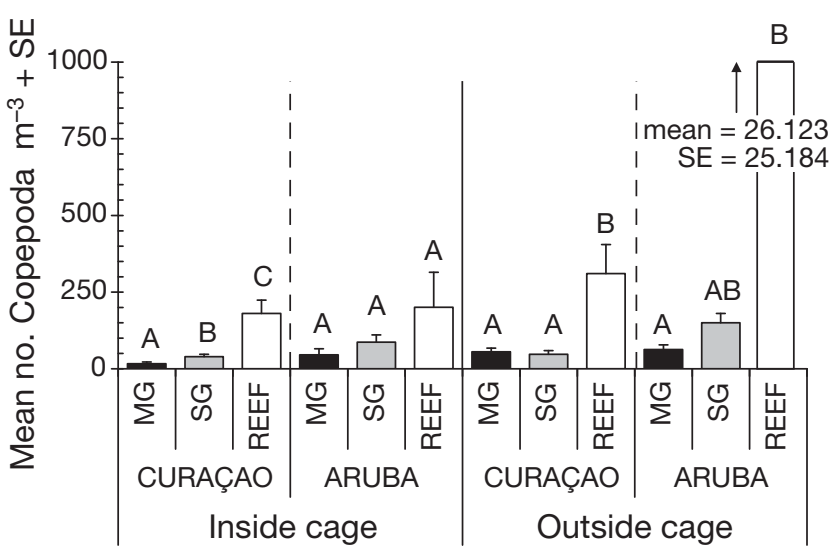

Fig. 4. Copepoda density in the plankton inside and outside the experimental growth cages in the mangroves (MG), seagrass beds (SG) and coral reef (REEF) in Curaçao and Aruba. Different letters represent significant differences among the 3 habitat types, per island, and separately for inside and outside the cages 
Table 6. p-values of multiple post hoc comparisons (Tukey HSD) among the 3 habitat types mangroves, seagrass beds and coral reef separately for the Copepoda densities in the plankton inside (in) and outside (out) the experimental growth cages, for Curaçao and Aruba

\begin{tabular}{|c|c|c|c|c|}
\hline Island & $\begin{array}{l}\text { In/out } \\
\text { cage }\end{array}$ & Habitat & Mangroves & $\begin{array}{c}\text { Seagrass } \\
\text { beds }\end{array}$ \\
\hline \multirow[t]{2}{*}{ Curaçao } & In & $\begin{array}{l}\text { Seagrass beds } \\
\text { Coral reef }\end{array}$ & $\begin{array}{c}0.042 \\
<0.001\end{array}$ & 0.013 \\
\hline & Out & $\begin{array}{l}\text { Seagrass beds } \\
\text { Coral reef }\end{array}$ & $\begin{array}{l}0.912 \\
0.010\end{array}$ & 0.004 \\
\hline \multirow[t]{2}{*}{ Aruba } & In & $\begin{array}{l}\text { Seagrass beds } \\
\text { Coral reef }\end{array}$ & $\begin{array}{l}0.227 \\
0.101\end{array}$ & 0.862 \\
\hline & Out & $\begin{array}{l}\text { Seagrass beds } \\
\text { Coral reef }\end{array}$ & $\begin{array}{l}0.676 \\
0.048\end{array}$ & 0.232 \\
\hline
\end{tabular}

tum, showed a strong selection for harpacticoids, an order of the subclass Copepoda (Alheit \& Scheibel 1982). Hence, it is clear that small-sized juvenile $H$. flavolineatum typically feed on Copepoda under natural conditions.

Cage experiments were used in the present study to follow growth of juvenile fish in the field under practically natural environmental and habitat conditions. Cages did not affect the food availability, since the commonly consumed food type (Copepoda) in the plankton inside and outside the cages did not show a significant difference in density in the 3 habitat types of the 2 islands, except for the mangrove cages in Curaçao where somewhat more food was available outside the cages. In all plankton samples in the 3 habitat types Copepoda showed the highest abundance, while all other taxa were less common or completely absent. A higher number of Copepoda was found on the coral reef compared to the seagrass beds and mangroves. Also growth rates for small juvenile Haemulon flavolineatum were highest on the coral reef of Aruba compared to the mangrove and seagrass nurseries, while such a trend was also present for Curaçao. This suggests that if all other factors are excluded, a higher availability of food on the coral reef could have resulted in the higher growth rates of small juvenile $H$. flavolineatum on the reef of Aruba and possibly also in Curaçao. This would only be true, however, if food is limiting in these 2 bay habitats. Nevertheless, many studies have found much higher juvenile fish densities within the mangrove and seagrass beds compared to the coral reef, including for $H$. flavolineatum (Nagelkerken et al. 2000a, Eggleston et al. 2004). This indicates that not only food availability is an important factor for juvenile fish when selecting a settlement habitat and raises the question: Why do recruits not settle massively on the coral reef where food availability can be higher?

Habitat selection and use by fishes are based on a strategy which maximises feeding and growth rates and minimises mortality risk by avoiding predation (Werner et al. 1983, Werner \& Hall 1988, Dahlgren \& Eggleston 2000). Therefore, it is assumed that fish shift habitats so that the ratio of mortality risk to growth rate is minimised. In vegetated habitats an increased amount of food, which can indirectly increase growth rates, and an increased refuge from predators are advantages for juvenile fishes (Sogard 1992). However, often a habitat which contains more food is also a habitat in which fishes experience a higher predation risk (Werner et al. 1983, Werner \& Hall 1988).

In the present study, a higher amount of food and higher growth rates (significant for Aruba, a trend in Curaçao) were found on the reefs of both islands compared to the mangrove and seagrass beds, but according to other studies a higher predation risk is also found on the reef compared to back-reef habitats (Shulman 1985, Chittaro et al. 2005). This was also true for predation on juvenile Haemulon flavolineatum (ranging from 3.1 to $4.5 \mathrm{~cm}$ TL) in a tethering experiment in the same 3 habitat types at Spanish Water during the same time period, where survival after 90 min of tethering was $0 \%$ on the coral reef versus 10 to $80 \%$ in mangroves and seagrass beds (depending on the distance to the reef) (M. Dorenbosch et al. unpubl. data). It thus appears that for minimisation of mortality rates, mangrove and seagrass beds are more attractive than the coral reef, while for maximisation of growth rates the reef is often more suitable. Juveniles therefore possibly have to make a decision between living on the reef, with higher food abundances but more predation risk, or living in safer lagoonal environments with less food; i.e. there appears to be a tradeoff between food/growth rates and predation/mortality risk. The higher abundances of early juvenile $H$. flavolineatum in mangroves or seagrass beds than on the reef thus suggests that a habitat with reduced predation risk is apparently more attractive than a habitat with higher food abundances.

Besides food availability and predation risk, various other factors can influence growth rates of fish, but they are assumed to be negligible in the present study. Mortality of caged juveniles during the experiments could hypothetically have affected growth rates by reducing the total number of fish per cage and leaving more space and food for the surviving fish. However, most juveniles disappeared late in the second half of the experiment, which suggests that mortality did not affect growth. Other studies also demonstrated that growth rates of juveniles were not 
significantly related to the density of fishes in a cage (Sogard 1992). Water depth of the cages, water temperature and salinity were equal among the habitats and could thus not have affected growth. Water clarity could potentially play an indirect role in fish growth, since a high water turbidity could result in a lower visual foraging efficiency and reduce feeding success, which could decrease growth rates (Grecay \& Targett 1996). The mangroves and seagrass beds in the present study indeed showed a much lower water clarity compared to the reef, which could indicate that juveniles on the reef fed more efficiently and therefore grew faster there compared to the mangrove/seagrass nurseries. However, all fishes were caged and could only forage within the boundaries of the cages, which were much smaller than the minimum water clarity. Therefore, water clarity did probably not contribute to differences in growth rates among habitats.

The present study shows that caged juvenile Haemulon flavolineatum at 2 Caribbean islands on average grew faster on the coral reef on Aruba compared to the putative mangrove and seagrass nursery habitats, while such a trend was also visible for Curaçao. A lower growth rate in these potential nurseries is possibly the result of a lower Copepoda abundance in the water layer, the food source which is most consumed by small juvenile $H$. flavolineatum according to the analysed gut contents and other published studies (Alheit \& Scheibel 1982, Cocheret de la Morinière et al. 2003). These results suggest that the coral reef serves as a more suitable habitat in some areas for small juvenile $H$. flavolineatum, in terms of growth and food availability. This contrasts with the nursery-role hypothesis as formulated by Beck et al. (2001). Probably due to the high predation pressure on the reef, juvenile densities are higher in mangroves and seagrass beds. It should be noted, however, that in the present study small juveniles were used and that these tradeoffs may change with ontogeny of the fishes, where mangroves and seagrass beds may become more important than the reef in terms of benthic food abundance for large juvenile $H$. flavolineatum, which turn to nocturnal benthic feeding.

Acknowledgements. This project was funded by the Netherlands Organization for Scientific Research (NWO) through a VIDI grant to I.N. Additional funding was received from the Department of Agriculture, Husbandry and Fisheries on Aruba (DLVV). We thank all staff and personnel of the Carmabi Institute in Curaçao and the DLVV for their hospitality and provision of research materials. We also thank S. L. J. Wartenbergh, A. de Groene, J. de Bie, R. van der Kant and J. Meijer for logistic support in the field. Furthermore, we thank F. Isabella from the Curaçao Sea Aquarium for advice and Zeerover harbor and seafood shop on Aruba for the use of their facilities. This is Centre for Wetland Ecology publication No. 488.

\section{LITERATURE CITED}

Alheit J, Scheibel W (1982) Benthic harpacticoids as a food source for fish. Mar Biol 70:141-147

Bak RPM (1975) Ecological aspects of the distribution of reef corals in the Netherlands Antilles. Bijdragen tot de Dierkunde 45(2):181-190

Baltz MB, Fleeger JW, Rakocinski CF, McCall JN (1998) Food, density, and microhabitat: factors affecting growth and recruitment potential of juvenile salt marshes. Environ Biol Fishes 53:89-103

Beck MW, Heck KL Jr, Able KW, Childers DL and others (2001) The identification, conservation, and management of estuarine and marine nurseries for fish and invertebrates. Bioscience 51:633-641

Blaber SJM (2000) Tropical estuarine fishes. Ecology, exploitation and conservation. Fish and aquatic resources, series 7. Blackwell Science, Oxford

Boeuf G, Payan P (2001) How should salinity influence fish growth? Comp Biochem Physiol C Toxicol Pharmacol 130: 411-423

Chittaro PM, Usseglio P, Sale PF (2005) Variation in fish density, assemblage composition and relative rates of predation among mangrove, seagrass and coral reef habitats. Environ Biol Fishes 72:175-187

Christensen JD, Jeffrey CFG, Caldow C, Monaco ME, Kendall MS, Appeldoorn RS (2003) Cross-shelf habitat utilization patterns of reef fishes in southwestern Puerto Rico. Gulf Caribb Res 14:9-27

Cocheret de la Morinière E, Pollux BJA, Nagelkerken I, van der Velde G (2002) Post-settlement life cycle migration patterns and habitat preference of coral reef fish that use seagrass and mangrove habitats as nurseries. Estuar Coast Shelf Sci 55:309-321

Cocheret de la Morinière E, Pollux BJA, Nagelkerken I, van der Velde G (2003) Diet shifts of Caribbean grunts (Haemulidae) and snappers (Lutjanidae) and the relation with nursery-to-coral reef migrations. Estuar Coast Shelf Sci 57:1079-1089

Connell SD (1998) Effects of predators on growth, mortality and abundance of a juvenile reef-fish: evidence from manipulations of predator and prey abundance. Mar Ecol Prog Ser 169:251-261

Dahlgren CP, Eggleston DB (2000) Ecological processes underlying ontogenetic habitat shifts in a coral reef fish. Ecology 81:2227-2240

Dahlgren CP, Kellison GT, Adams AJ, Gillanders BM and others (2006) Marine nurseries and effective juvenile habitats: concepts and applications. Mar Ecol Prog Ser 312:291-295

de Haan D, Zaneveld JIS (1959) Some notes on tides in Annabaai harbour, Curaçao, Netherlands Antilles. Bull Mar Sci Gulf Caribb 9:224-236

> Dorenbosch M, Grol MGG, Christianen MJA, Nagelkerken I, van der Velde G (2005) Indo-Pacific seagrass beds and mangroves contribute to fish density and diversity on adjacent coral reefs. Mar Ecol Prog Ser 302:63-76

Eggleston DB, Dahlgren CP, Johnson EG (2004) Fish density, diversity, and size-structure within multiple back-reef habitats of Key West National Wildlife Refuge. Bull Mar Sci 75:175-204

Gillanders BM, Able KW, Brown JA, Eggleston DB, Sheridan PF (2003) Evidence of connectivity between juvenile and adult habitats for mobile marine fauna: an important component of nurseries. Mar Ecol Prog Ser 247:281-295

> Grecay PA, Targett TE (1996) Effects of turbidity, light level and prey concentration on feeding of juvenile weakfish 
Cynoscion regalis. Mar Ecol Prog Ser 131:11-16

> Heck KL Jr, Hays G, Orth RJ (2003) Critical evaluation of the nursery role hypothesis for seagrass meadows. Mar Ecol Prog Ser 253:123-136

Keys AB (1928) The weight-length relation in fishes. Zoology 14:922-925

McCormick MI (1998) Condition and growth of reef fish at settlement: Is it important? J Ecol 23:258-264

> Nagelkerken I, Dorenbosch M, Verberk WCEP, Cocheret de la Morinière E, van der Velde G (2000a) Importance of shallow-water biotopes of a Caribbean bay for juvenile coral reef fishes: patterns in biotope association, community structure and spatial distribution. Mar Ecol Prog Ser 202:175-192

Nagelkerken I, van der Velde G, Gorissen MW, Meijer GJ, van 't Hof $T$, den Hartog C (2000b) Importance of mangroves, seagrass beds and the shallow coral reef as a nursery for important coral reef fishes, using a visual census technique. Estuar Coast Shelf Sci 51:31-44

> Nagelkerken I, Kleijnen S, Klop T, van den Brand RACJ, Cocheret de la Morinière E, van der Velde G (2001) Dependence of Caribbean reef fishes on mangroves and seagrass beds as nursery habitats: a comparison of fish faunas between bays with and without mangroves/ seagrass beds. Mar Ecol Prog Ser 214:225-235

Nagelkerken I, Roberts CM, van der Velde G, Dorenbosch M, van Riel MC, Cocheret de la Morinière E, Nienhuis $\mathrm{PH}$ (2002) How important are mangroves and seagrass beds

Initial editorial responsibility: Howard Browman, Storebø, Norway; Final editorial responsibility: Matthias Seaman, Oldendorf/Luhe, Germany for coral-reef fish? The nursery hypothesis tested on an island scale. Mar Ecol Prog Ser 244:299-305

Ogden JC, Ehrlich PR (1977) The behaviour of heterotypic resting schools of juvenile grunts (Pomadasyidae). Mar Biol 42:273-280

> Parrish JD (1989) Fish communities of interacting shallowwater habitats in tropical oceanic regions. Mar Ecol Prog Ser 58:143-160

Shulman MJ (1985) Recruitment of coral reef fishes: effects of distribution of predators and shelter. Ecology 66: 1056-1066

> Shulman MJ, Ogden JC (1987) What controls tropical reef fish populations: recruitment or benthic mortality? An example in the Caribbean reef fish Haemulon flavolineatum. Mar Ecol Prog Ser 39:233-242

Sogard SM (1992) Variability in growth rates of juvenile fishes in different estuarine habitats. Mar Ecol Prog Ser 85:35-53

Sutherland WJ (1996) From individual behaviour to population ecology. Oxford University Press, New York, USA

> Verweij MC, Nagelkerken I, Wartenbergh SLJ, Pen IR, van der Velde G (2006) Caribbean mangroves and seagrass beds as diurnal feeding habitats for juvenile French grunts, Haemulon flavolineatum. Mar Biol 149:1291-1299

> Werner EE, Hall DJ (1988) Ontogenetic habitat shifts in bluegill: the foraging rate-predation risk trade-off. Ecology 69:1352-1366

Werner EE, Mittelbach GG, Hall DJ, Gilliam JF (1983) Experimental tests of optimal habitat use in fish: the role of relative habitat profitability. Ecology 64:1525-1539

Submitted: June 4, 2007; Accepted: April 6, 2008

Proofs received from author(s): August 12, 2008 